\title{
Social media within the context of Human Resource Management
}

\begin{tabular}{|c|c|}
\hline $\begin{array}{l}\text { Book Title: } \\
\text { Social media } \\
\text { selection and } \\
\text { Theory, pract } \\
\text { challenges }\end{array}$ & $\begin{array}{l}\text { n employee } \\
\text { recruitment: } \\
\text { ce, and current }\end{array}$ \\
\hline Book Cover: & \\
\hline 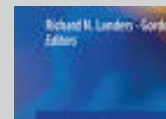 & Gestinit \\
\hline $\begin{array}{l}\text { Social Mec } \\
\text { in Employ } \\
\text { Selection } \\
\text { Recruitme } \\
\text { tmex meneren }\end{array}$ & $\begin{array}{l}\text { lia } \\
\text { ee } \\
\text { and } \\
\text { nt } \\
\text { estangs }\end{array}$ \\
\hline $\begin{array}{l}\text { Authors: } \\
\text { Richard N. Lar } \\
\text { Gordon B. Sch }\end{array}$ & $\begin{array}{l}\text { iders } \\
\text { imidt }\end{array}$ \\
\hline $\begin{array}{l}\text { ISBN: } \\
\text { 978-3-319-29 }\end{array}$ & $989-1$ \\
\hline $\begin{array}{l}\text { Publisher: } \\
\text { Springer Inter } \\
\text { Publishing, } 20 \\
€ 55,92 * \\
\text { *Book price at t }\end{array}$ & $\begin{array}{l}\text { national } \\
16, \\
\text { ime of review }\end{array}$ \\
\hline $\begin{array}{l}\text { Review Title: } \\
\text { Social media } \\
\text { context of Hu } \\
\text { Management }\end{array}$ & $\begin{array}{l}\text { within the } \\
\text { man Resource }\end{array}$ \\
\hline $\begin{array}{l}\text { Reviewers: } \\
\text { Zikhona Dlaza } \\
\text { Willie T. Chiny }\end{array}$ & ${ }^{1}$ \\
\hline $\begin{array}{l}\text { Affiliations: } \\
{ }^{1} \text { Department } \\
\text { Management, } \\
\text { Fort Hare, Sol }\end{array}$ & $\begin{array}{l}\text { of Business } \\
\text { University of } \\
\text { th Africa }\end{array}$ \\
\hline $\begin{array}{l}\text { Correspondin } \\
\text { Willie Chinyan } \\
\text { chinyaz@gma }\end{array}$ & $\begin{array}{l}\text { g author: } \\
\text { nurindi, } \\
\text { il.com }\end{array}$ \\
\hline Read online: & \\
\hline 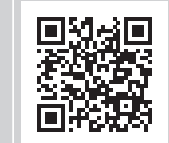 & $\begin{array}{l}\text { Scan this } Q R \\
\text { code with your } \\
\text { smart phone or } \\
\text { mobile device } \\
\text { to read online. }\end{array}$ \\
\hline
\end{tabular}

\section{Introduction}

Social media in employee selection and recruitment: Theory, practice and current challenges is a book edited by Richard N. Landers and Gordon B. Schmidt. The book offers valuable information for both researchers and practitioners around the concept of social media usage within the context of work. It seeks to explore the role played by social media in decision-making regarding issues such as the qualifications of job applicants and how social media can be used to increase the number of jobs. The purpose here is to build a cohesive research literature base surrounding social media usage in Human Resources Management activities such as selection. The strengths of the book lie in (1) the ability to distinguish selection from other aspects of the hiring process. By referring to selection as a system that employers use to determine the qualifications of job applicants and the decision-making process used to act upon that information (Farr \& Tippins, 2010), (2) it identifies six major research concerns in social media in selection from a variety of perspectives and theoretical frameworks and (3) provides a critical evaluation of the current applications and practical guidelines for social media in selection. Authors across academia and industry contributed to the chapters of the book by organising and presenting relevant research perspectives on the subject matter. The book is split into two sections. The first section presents a set of chapters targeted primarily at researchers and practitioners. The second section highlights the challenges and limitations of social media when used as part of employee selection and recruitment.

\section{Basic premise of the book}

The practice of using social media for pre-employment screening and selection has become more popular. This book emphasises that 'social media' is a complex term that needs to be carefully defined. It conceptualises social media as a broader set of social technologies, not just merely social network sites. The authors of this book place cadence on a multi-layered view of social media (i.e. including any Internet technology that enables the sharing of content created by users with other users). The emphasis is supported by Haenlein and Kaplan (2010) that social media is a group of Internet-based applications that build on the ideological and technological foundations of Web 2.0, and that allow the creation and exchange of user-generated content. This encompasses an enormous variety of online applications, such as social networking sites, blogs, social bookmarking, social news, video sharing, wikis, event sharing, art sharing, collaborative projects, music and audio sharing, and virtual worlds. This premise makes the book rich in covering a range of topics that may be of interest to different people.

The authors further acknowledge challenges faced by the process of selection, and social media can assist in this regard. One of the challenges this book focuses on is the issue of reliability and validity of information available via social media. Brown and Vaughn (2011) concur with the authors that one of the most problematic issues surrounding social media information for personnel decisions lies in the limited evidence of reliability and validity to support appropriateness and meaningfulness of the information gathered from social media. The book also points to future directions for researchers by discussing on the future of social media use and recruitment as well as areas needed for theoretical and empirical research.

\section{Structure, content and style of the text}

The structure of the book is well presented and reads well even to a non-technical audience, making the book less intimidating. A common theme running through the entire book is the role of social media and the subsequent chapters. The starting chapter is the introduction that gives an

How to cite this book review: Dlaza, Z., \& Chinyamurindi, W.T. (2017). Social media within the context of Human Resource Management. SA Journal of Human Resource Management/SA Tydskrif vir Menslikehulpbronbestuur, 15(0), a899. https://doi.org/10.4102/sajhrm. v15i0.899

Copyright: ( 2017. The Authors. Licensee: AOSIS. This work is licensed under the Creative Commons Attribution License. 
overview of social media in employee selection and recruitment. The ensuing chapters appear to be grounded in various empirical studies. Furthermore, all the chapters are unique as the editors solicited a range of authors to write for particular audiences. The book succeeds in presenting a balanced academic and practitioner perspective by providing guidelines to employers who intend to use and currently using social media and the role social media strategy could play in supporting employers in selection and recruitment.

\section{Conclusion}

Social media in employee selection and recruitment is a contribution to organisations where researchers and practitioners will continue to benefit. Its chapters cover a wide range of topics that need to be considered when using social media in employment selection and recruitment. Contributions from both academia and researchers provide well-researched and substantiated viewpoints which make the book worthy of consideration.

\section{References}

Brown, V.R., \& Vaughn, E.D. (2011). The writing on the (Facebook) wall: The use of social networking sites in hiring decisions. Journal of Business and Psychology, 26 219-225. https://doi.org/10.1007/s10869-011-9221-x

Farr, J.L., \& Tippins, N.T. (2010). Handbook of employee selection. New York: Routledge.

Haenlein, M., \& Kaplan, A. (2010). Users of the world, unite! The challenges and opportunities of social media. Business Horizons, 53(1), 59-68. https://doi. org/10.1016/j.bushor.2009.09.003 